\title{
Entrenched Board in New Public Firms: An Empirical Study of Chinese IPOs
}

\author{
Fitriya Fauzi, Abdul Basyith \\ The University of Muhammadiyah Palembang, Palembang, Indonesia \\ Nirosha Hewa-Wellalage, Gaoxiang Wang \\ The University of Waikato, Hamilton, New Zealand
}

This study empirically investigates the impact of managerial entrenchment on firm financial performance of Chinese firms initial public offerings (IPOs). Using 142 firms listed in the Shenzhen Stock Exchange (SZSE), which was collected from the Guotaian Research Service Center (GTA-RSC) databases, this study uses two proxies to measure firm performance and three proxies to measure managerial entrenchment. The two proxies for firm performance are Tobins' $\mathrm{Q}$ and return on assets (ROA), and the three proxies for managerial entrenchment are entrenchment 1, entrenchment 2, and entrenchment 3. These three entrenchment proxies are derived from the principal component analysis (PCA). Though previous studies of managerial entrenchment and firm performance variables suffer from endogeneity, with respect to the corporate governance it is unclear as to which variables are endogenous and which are exogenous. This study confirms that the data are linear and no endogeneity issue should be address in this study, but only heteroskedasticity, non-normality for Tobins' $\mathrm{Q}$ are a problem, therefore, the regression method employed for Tobins' $\mathrm{Q}$ is the generalised least square (GLS) and the ordinary least square (OLS) between estimators for ROA. The regression result for Tobins' $Q$ reveals that managerial entrenchment is negatively impact on firm performance. The results are in contradiction to the stewardship theory for new firms whereas the managerial entrenchment for new firms is positive. Furthermore, only one entrenchment proxy yields a significant coefficient. In conclusion, the negative results of entrenchment proxies were caused by the different institutional structures and legal systems which are the Chinese corporations that are still largely owned and controlled by a state and hence the centralised state controlled was responsible for all managerial actions.

Keywords: managerial entrenchment, firm performance, Chinese firms initial public offerings (IPOs)

\section{Introduction}

The earliest beginnings of Shenzhen Stock Exchange (SZSE) can be traced back to 1986. The Shenzhen Development Bank started the first security translation at the securities company counter. After the Shenzhen City Investment Securities and the Bank of China Securities Department was opened, several companies also

Fitriya Fauzi, Ph.D., Economic Faculty, The University of Muhammadiyah Palembang.

Abdul Basyith, Ph.D. Candidate, Economic Faculty, The University of Muhammadiyah Palembang.

Nirosha Hewa-Wellalage, Ph.D., Waikato Management School, The University of Waikato.

Gaoxiang Wang, Ph.D. Candidate, Waikato Management School, The University of Waikato.

Correspondence concerning this article should be addressed to Fitriya Fauzi, The University of Muhammadiyah Palembang, Indonesia, Jl. A. Yani 13 Ulu Palembang, Indonesia. E-mail: fitriya@umpalembang.ac.id. 
issued and traded stocks, and then the rudimentary form of SZSE was structured. Shenzhen City Hall had introduced the decision to build up the SZSE in November 1989 and SZSE was founded in 1st December, 1990. The SZSE was formally opened for business on 3rd July, 1991. The SZSE was regulated by the Shenzhen branch of the People's Bank of China. After 1st April, 1993, the SZSE was established by the Shenzhen Securities Management Committee. With the SZSE trading gradually becoming active, the number of listed companies gradually expanded. The SZSE provides a centralized trading place for securities. It also organizes and supervises those securities trading under the direct supervision and management of the China Securities Regulatory Commission. Being committed to multi-level security market construction, the SZSE strives to create an open and fair market environment.

The main functions of the exchange include developing the trading rules, arranging IPO listings, supervising IPO listings, organizing and monitoring securities trading, supervising the investors and listed companies, administering and disclosing market information, and any other functions licensed by the China Securities Regulatory Commission. The SZSE market capitalization and trading volume are also increasing regarding to the increased number of listed stocks and number of investors. As one of the two stock exchanges in China mainland, the SZSE is growing with whole China securities markets. After 22 years' development, the SZSE has successfully built a national level securities market in a new city through the use of modern technology. Now the SZSE is playing a very important role in establishing the modern enterprise system, promoting the adjustment of economic structure, optimizing the allocation of resources, and spreading the knowledge of market economy. In China there is a position contributing to corporate governance known as "supervisors". Listed companies are required to establish a board of supervisors, consisting of no fewer than three members and who must meet at least every six months. Supervisors have a term of three years which may be renewed.

The supervisor role includes five main responsibilities. First, supervisors are responsible for supervising directors and management to ensure their behavior which has not violated any laws or regulations and that they abide by the articles of association of the company and the resolution of the shareholders' assembly. Secondly, they are responsible for the inspection of financial status and other accounting documents. Thirdly, they are responsible for checking the accounting reports, business reports, profit distribution, and financial data that board of directors submits to the shareholders' meeting. Fourthly, they have the right to the company's management and give forward suggestions. Fifthly, they are responsible for the resolution of the shareholders' meeting. Commitment to their job is comprehensive and responsible. According to Chinese Company Law Act 2005, a listed company shall set up a board of supervisors, not less than three members, who must meet at least once every six months. The tenure of office of the supervisor is three years, with provision for reappointment when that tenure expires. The number of meetings per year may represent the supervisory effort expended.

Two significant parties that own corporate shares in China are state-owned enterprises (SOEs) and legal persons. Corporate legal persons are defined by "People's Republic of Enterprise Legal Person Registration Regulations" and "Republic of China Company Registration"; the individuals and organizations report to the national law with the amount of money, business name, articles of association, organization, address and other statutory requirements, and must be able to independently bear civil liability, and be approved and registered by the competent authorities to obtain legal personality. In many corporate SOEs, legal persons own more than $60 \%$ of the shares. This study a high correlation between SOE and legal person ownership variable, as government 
officers are the legal persons of many of the listed companies. Accordingly, the non-traded share percentage may become important. In many instances the non-corporate legal person is a government officer.

Further, to support the Chinese market economy, particularly Chinese capital market, there are some regulations promulgated. In 2001, the China Securities Regulatory issued "the leading opinion on building up the institutional of independent board director in the listed company". In 2002, the China Securities Regulatory and State Economics and Trade Commission issued; first, the rules of governance of the listed companies; second, the management standard of the listed company. In 2003, State-Owned Assets Supervision Commission was established. These rules are aimed at: first, preventing the big shareholders from seizing the benefits of the listed company; second, improving the board structure and functions. These actions were aimed at improving an effective governance conducts which affecting firms credibility and performance. Due to different characteristics of governance conducts, institutional structures, legal systems and environments, it is interesting to investigate the impact of managerial entrenchment on firm performance, particularly new listed firms in the SZSE.

Further, it is important to examine the degree of managerial entrenchment in new listed firms, because it is believed that most of the new listed firms have less strict of the corporate governance conduct. Further, it is important to examine the degree of managerial entrenchment in new Chinese firms, because China is playing a very important role in establishing the modern enterprise system in the world, and one of the largest market economies. Some of new listed firms are from family business, hence duality positions are suspected, thus may contribute to the managerial entrenchment and may raise the conflict of interest between shareholders.

\section{Research Problem}

The research problem posed in this study is whether managerial entrenchment is positively related to firm performance of IPOs firms.

\section{Literature}

There is no single model of corporate governance. Governance practices vary not only across countries but also across firms and industry sectors, for example, product market competition, structure of capital and labor markets, and the regulatory and legal environments. Shleifer and Vishny (1997) argued that much of the differences in corporate governance systems around the world stem from varying regulatory and legal environments. In addition, product market competition can reduce the scope for managerial inefficiency. This is because there are fewer rents to be expropriated when markets are competitive. Competition also provides a

benchmark by which the performance of the firm can be judged when compared with the performance of other firms in a similar sector.

Corporate governance mechanisms should be able to minimise the conflict of interests within the company. However, inappropriate conducts of corporate governance mechanisms can be a source of managerial entrenchment. Weisbach (1988) defined managerial entrenchment as a situation where managers gain much power to further their own benefits rather than the benefits of shareholders. Furthermore, Shleifer and Vishny (1989) defined managerial entrenchment as an act of managers based on their own interest in judgment which investment gives them more benefits because they obtain more latitude in determining corporate strategy, thus reduce the probability of being replaced, pursue higher wages and larger perquisites from shareholders.

Furthermore, effective corporate governance should be able to monitor management activities. Therefore, 
in order for boards to effectively fulfil their monitoring role they must have some degree of independence from management, thus independent directors on board are important. Although the independent directors on board in theory should represent the interests of shareholders and the company, in practice they often become part of the management of the corporation, and they can easily become entrenched as well. This is particularly the case when independent directors are compensated for their activities, and are themselves responsible for overseeing executive and board remuneration.

Corporate governance mechanisms such as board structures have been widely tested by present researchers; most of them focus on the effect of outside directors, board size, and female directors' impact, and CEO duality on firm performance. Gompers, Ishii, and Metrick (2003), and Bebchuk, Cohen, and Ferrel (2005) documented a negative relationship between various entrenchment indices and Tobins' $\mathrm{Q}$ or firm operating performance. This evidence suggests that entrenchment is detrimental to firm value.

An effective of corporate governance mechanisms should improve internal and external governance structures in China. High quality audits, higher stock ownership of senior managers, higher block shareholders, and less interference of the SOEs are of examples in improving corporate mechanisms in China. In the end, an effective corporate governance mechanisms lead to good performance (Gao \& Kling, 2008). In addition, firms with larger controlling shareholders, with smaller supervisory boards, and having CEO duality, are more likely to choose low quality auditors, and hence lead to low firm performance (Z. J. Lin \& M. Liu, 2009).

Moreover, CEO characteristics play an important role in explaining the IPO performance. According to Fan, Wong, and Zhang (2007), CEO's political ties are negatively associated with post IPOs' returns and other accounting characteristics, because politically connected CEOs are more likely to have boards populated by current or former government bureaucrats rather than professionals in China. Likewise, Li and Naughton (2007) found that CEO duality is positively associated with long-term IPO performance in China. In contrast, Chahine and Tohmé (2009) found that CEO duality is negatively related with short-term IPO underpricing in Arabian countries. Moreover, board characteristics do have some explanatory power on IPO aftermarket performance in the Chinese market (Li \& Naughton, 2007). State ownership is significantly negatively connected to short-term IPO performance in China (Gu, 2003). Furthermore, the CEO age is potentially important for China which has given a continuing general reverence given to older people who are viewed as having acquired more wisdom. This may also explain why all presidents of the Communist party in China have been over 60 years of age. The majority of Chinese companies do disclose age.

Rosenstein and Wyatt (1990) found that the proportion of outside directors increases shareholders' wealth by documenting a positive stock price reaction at the announcement of the appointment of outside directors. In contrast, Yermack (1996) found that the percentage of outside directors has no impact on firm performance, and firm value is a decreasing function of board size. In addition, Baysinger and Butler (1985), Hermalin and Weisbach (1991), and Bhagat and Black (1997) found that various characteristics of board composition have no impact on firm performance. Thus, the evidence for the importance of outside directors is mixed.

The roles of the CEO and the chairman of the board (COB) are all crucial but different. The CEO is responsible for leading the firm's management, whereas the $\mathrm{COB}$ is responsible for leading the board. The separation of the $\mathrm{CEO}$ and the $\mathrm{COB}$ are mainly intended to reduce self-interest rather than shareholders' interest. However, sometimes, one individual often holds the CEO and the COB in the same time, known as a CEO duality. According to the agency theory, Jensen and Meckling (1976) suggested that CEO duality is not 
ideal for firm value and performance because it could compromise the board's necessary monitoring role of the CEO. Stewardship theory (Donaldson, 1990; Muth \& Donaldson, 1998), in contrast, asserted that CEO duality may be ideal for firm value and performance because of the unity of leadership and control it presents. However, Fama and French (2001) and H. DeAngelo, L. DeAngelo, and Stulz (2006) reconciled agency theory and stewardship theory of board leadership by assessing whether the probability a CEO concentrating his/her power by combining the $\mathrm{COB}$ affects firm performance.

\section{Hypothesis Development}

According to the stewardship theory, the impact of CEO power concentration on firm performance is positive in early stage, and the influence becomes more negative as firm's life-cycle matures, supporting the agency theory. CEO power concentration is beneficial to determine the future direction for growth when the firm is in early stage, while CEO power concentration is detrimental when the firm is in the mature stage at which it requires check-and-balance rather than power concentration. Therefore, the impact of CEO duality should be positive owing to the required demand of leadership for right directions.

According to stewardship theory, the hypothesis for this study is formulated as follow:

$\mathrm{H}_{0}$ : Managerial entrenchment is positively related to firm performance of IPOs firms.

\section{Method}

Data in this study were collected from the Guotaian Research Service Center (GTA-RSC). From the period of 1999 to 2005, there were only 142 IPOs. Hence, an unbalanced panel data of 142 firms were observed.

Variables are largely adopted from previous studies. To investigate the impact of managerial entrenchment and firm performance, the researchers employ two proxies for firm performance used as dependent variable; Tobins' $\mathrm{Q}$ and return on assets (ROA). Tobins' $\mathrm{Q}$ is calculated from the market value to book value divided by total equity. ROA is calculated from net income after interest and taxes divided by total assets.

Managerial entrenchment serves as explanatory variable, and the researchers use three proxies to measure managerial entrenchment. These three proxies were derived from the principal component analysis (PCA). The PCA is used to determine the component factors for each managerial entrenchment proxies. A set of corporate governance characteristics that are likely to be associated with manager's own interests is used such as the board size, the percentage of independent directors, the percentage of female directors on board, the CEO age, the CEO gender, the CEO entire experience in the company, the CEO duality are independent variables used to derive component factors for managerial entrenchment proxies.

There are some benefit using the PCA; first, the PCA allows to determine a combination from a wide set of corporate governance variables in constructing a single entrenchment proxy; second, the PCA allows data reductions; third, the PCA produces weights, hence the entrenchment proxies will explain much of the variance in the group of corporate governance variables.

Tables 1 and 2 present the results from PCA. In Table 1 (Panel A), there are three components that having eigenvalue higher than one, and these three components explain $58.532 \%$ of the total variance. Therefore, three component factors will be used for entrenchment proxies; hence these three component factors will be referred as entrenchment 1, entrenchment 2, and entrenchment 3. In Table 2 (Panel B), only factor loadings which have correlation \pm 0.6 are included as factor loadings combined for each component factor. Entrenchment 1 is a 
combination of CEO entire experience in the company and the percentage of independent directors. Entrenchment 2 is a combination of board size and the percentage of female directors. Entrenchment 3 is a combination of the CEO duality and the CEO gender. In addition, firm size, leverage and the dummy for IPOs year serve as control variables. Market capitalisation is used as firm size indicator, and total debt-to-equity ratio is used as leverage ratio.

Table 1

Panel A: Total Variance Explained

\begin{tabular}{lllc}
\hline \multirow{2}{*}{ Component } & \multicolumn{3}{c}{ Initial eigenvalues } \\
\cline { 2 - 4 } & Total & \% of variance & Cumulative \% \\
\hline 1 & 1.326 & 21.939 & 21.939 \\
2 & 1.136 & 18.931 & 40.870 \\
3 & 1.06 & 17.662 & 58.532 \\
4 & 0.95 & 15.837 & 74.368 \\
5 & 0.848 & 14.133 & 88.501 \\
6 & 0.69 & 11.499 & 100.000 \\
\hline
\end{tabular}

Table 2

Panel B: Rotated Component Matrix

\begin{tabular}{lccc}
\hline \multirow{2}{*}{ Component } & \multicolumn{3}{c}{ Component } \\
\cline { 2 - 4 } & 1 & 2 & -0.609 \\
\hline CEO duality & -0.166 & 0.087 & 0.732 \\
CEO gender & -0.102 & 0.119 & 0.139 \\
CEO experience & 0.779 & -0.182 & 0.218 \\
Board size & -0.082 & -0.791 & -0.072 \\
NED & 0.752 & 0.279 & 0.314 \\
Female directors & -0.032 & 0.677 & \\
Rotation method: Varimax with Kaiser normalisation & & \\
\hline
\end{tabular}

The researchers use panel data which allow the unobservable heterogeneity for each observation in the sample to be eliminated and multicollinearity among variables to be alleviated. Maddala and Lahiri (2008) specified problems that might be present in the regression model, such as heteroskedasticity, multicollinearity, and endogeneity problems. Those problems cause inconsistency of the ordinary least square (OLS) estimates.

As can be seen in the Tables 6 and 7, most cross-correlations for the independent variables are fairly small, thus, giving less cause for concern about the multicollinearity problem. Further, a joint information matrix (IM) test of heteroskedasticity, skewness, and non-normal kurtosis is employed. Tables 3 and 4 present the joint IM test, when Tobins' Q and ROA respectively are used as dependent variable in each regression model. The joint IM test, when Tobins' $\mathrm{Q}$ used in the model, rejects the model assumption that $y \sim N\left(x^{\prime} \beta, \sigma^{2} \mathrm{I}\right)$, because $p=$ 0.0000 in the total row. The decomposition indicates that all three assumptions of homoscedasticity, symmetry and normal kurtosis are rejected (see Table 3). In contrast, the joint IM test, when ROA used in the model, rejects the model assumption that $y \sim N\left(x^{\prime} \beta, \sigma^{2} \mathrm{I}\right)$, because $p=0.8533$ in the total row. The decomposition indicates that all three assumptions of homoscedasticity, symmetry, and normal kurtosis are accepted when ROA used as dependent variable in the model (see Table 4). 
Table 3

Cameron and Trivedi Decomposition of IM-test for Tobins' $Q$

\begin{tabular}{lccl}
\hline Source & Chi2 & $d f$ & $p$ \\
\hline Heteroskedasticity & 121.45 & 38 & 0.0000 \\
Skewness & 40.08 & 9 & 0.0000 \\
Kurtosis & 5.66 & 1 & 0.0174 \\
Total & 167.19 & 48 & 0.0000 \\
\hline
\end{tabular}

Table 4

Cameron and Trivedi Decomposition of IM-test for ROA

\begin{tabular}{lrcc}
\hline Source & Chi2 & $d f$ & $p$ \\
\hline Heteroskedasticity & 26.38 & 38 & 0.9224 \\
Skewness & 8.76 & 9 & 0.4596 \\
Kurtosis & 2.71 & 1 & 0.1000 \\
Total & 37.58 & 48 & 0.8533 \\
\hline
\end{tabular}

To estimate the firm performance, this equation is the first point to begin, the model is as follows:

$$
\begin{gathered}
y_{i t}=\alpha+x_{i t}^{\prime} \beta+\cdots+x_{i n}^{\prime} \beta_{n}+u_{i t} \\
u_{i t}=\mu_{i}+\lambda_{t}+v_{i t} \\
i=1, \ldots, N ; t=1, \ldots, T
\end{gathered}
$$

where $\mu_{i}$ denotes the unobservable individual effect, $\lambda_{t}$ denotes the unobservable time effect, and $v_{i t}$ is the remainder stochastic disturbance term.

While endogeneity is prevalent across many aspects of corporate finance, the relationship between corporate governance and firm performance is likely to be infiltrated with the endogeneity problem. It is important that endogeneity is taken into account as the presence of unobserved influences is likely to generate a degree of correlation between regressors and the error terms, which leads to biased estimates of the regressors' coefficients. Theory and empirical work suggest that corporate governance is dynamically endogenous with respect to firm performance. Wintoki, Linck, and Netter (2009) asserted that any type of endogeneity, such as past performance, simultaneity and unobservable heterogeneity, is likely to be present between board structure and firm performance. In contrast to Wintoki et al. (2009), using the Durbin-Wu-Hausman test for endogeneity, this study confirms no endogeneity. However, most of those previous studies were based in the US, which has different characteristics, different corporate governance practices, and different institutional characteristics from China, thus the result of the endogeneity test of this study cannot reject the null hypothesis.

Furthermore, a number of studies have found a non-linear relationship between managerial ownership and performance, which under the agency model, indicates managerial entrenchment (McConnell \& Servaes, 1990; Short \& Keasey, 1999; Hermalin \& Weisbach, 1991; Holderness, Kroszner, \& Sheehan, 1999; Morck, Shleifer \& Vishny, 1988). This study confirms the linearity, when Tobins's Q is used as dependent variable in the model, using Box-Cox test, with results of -0.3636 , which is approximated as close to one. Because ROA contains a negative value, thus linearity is more appropriate.

According to the specification test results for heteroskedasticity, skewness, kurtosis, endogeneity, and linearity of the data, thus the regression method employed for each dependent variable is different; for Tobins' Q, the GLS is appropriate because the assumptions of homoscedasticity of errors fail, as for ROA, the OLS between estimators is appropriate because of the short time period and many observations. 
Then the regression model is specified as:

$$
F P_{i t}=\beta_{0}+E 1_{i t}+E 2_{i t}+E 3_{i t}+F S_{i t}+C V_{i t}+\varepsilon_{i t}
$$

where:

FP: Firm performance;

E1: Managerial entrenchment 1;

E2: Managerial entrenchment 2;

E3: Managerial entrenchment 3;

FS: Firm size;

Lev: Leverage;

$C V$ : Dummy for IPOs year.

\section{Result and Discussion}

Table 5 presents the descriptive statistics for all variables. The mean value for Tobins' $\mathrm{Q}$ is 2.5892 , with a range 0.6965 to 12.8508 , suggesting that most of IPOs firms have high firm performance based on market value. This is evidence that the markets react positively to IPOs firms. The mean value for ROA is 0.0408 , with a range $0.0000-0.3903$ to 0.2716 , indicating that most of IPOs firms have a lower performance based on accounting measure. The mean value for CEO duality is 0.8075 , suggesting that approximates to $80 \%$ of the CEOs are also the $\mathrm{COB}$, which hinders board from playing an effective monitoring role. The mean value for non-executive directors is 0.2149 , suggesting that new public firms in China have lower outside directors in the beginning of their listing, hence indicating an effective monitoring role within the board. The mean value for female directors on board is 0.1012 with a range 0.1045 to 0.6000 , suggesting that the presence of woman of Chinese firms' board is low. The mean value of entrenchment one is 1.93 with a range 0.0000 to 7.5000 , suggesting that the CEO experience and non-executive directors' variables are a minor cause in creating an entrenched board. The mean value of entrenchment two is 1.0650 with a range 0.4771 to 1.4795 , suggesting that board size and female directors on board variable are a major cause in contributing an entrenched board. The mean value of entrenchment three is 0.8306 with a range 0.0000 to 2.0000 , suggesting that the CEO duality and the CEO gender variables are also a major cause in contributing entrenched board. Overall, higher value of entrenchment indicates greater managerial entrenchment; thus, greater managerial entrenchment yields lower firm value.

Table 5

Descriptive Statistics

\begin{tabular}{llllcc}
\hline Variable & Obs. & Mean & Std. dev. & Min. & Max. \\
\hline Tobins' Q & 426 & 2.5892 & 1.8979 & 0.6965 & 12.8508 \\
ROA & 426 & 0.0408 & 0.0583 & -0.3903 & 0.2716 \\
Board size & 426 & 0.9609 & 0.1138 & 0.3010 & 1.2304 \\
Female directors & 426 & 0.1012 & 0.1045 & 0.0000 & 0.6000 \\
NED & 426 & 0.2149 & 0.1678 & 0.0000 & 1.5000 \\
CEO duality & 425 & 0.8075 & 0.3947 & 0.0000 & 1.0000 \\
CEO experience & 425 & 0.0235 & 0.1518 & 0.0000 & 1.0000 \\
CEO age & 425 & 1.7176 & 1.4309 & 0.0000 & 6.0000 \\
Firm size & 426 & 1.8182 & 1.2656 & 0.9334 & 5.7302 \\
\hline
\end{tabular}


(Table 5 continued)

\begin{tabular}{llllll}
\hline Variable & Obs. & Mean & Std. dev. & Min. & Max. \\
\hline Leverage & 426 & 0.1102 & 0.2055 & 0.0000 & 1.5899 \\
Entrenchment 1 & 486 & 1.9323 & 1.3803 & 0.0000 & 7.5000 \\
Entrenchment 2 & 486 & 1.0650 & 0.1320 & 0.4771 & 1.4795 \\
Entrenchment 3 & 486 & 0.8306 & 0.3900 & 0.0000 & 2.0000 \\
IPOs_2000 & 426 & 0.3662 & 0.4823 & 0.0000 & 1.0000 \\
IPOs_2001 & 426 & 0.3451 & 0.4760 & 0.0000 & 1.0000 \\
IPOs_2002 & 426 & 0.0704 & 0.0837 & 0.0000 & 1.0000 \\
IPOs_2003 & 426 & 0.0070 & 0.0837 & 0.0000 & 1.0000 \\
IPOs_2004 & 426 & 0.0000 & 0.0000 & 0.0000 & 0.0000 \\
IPOs_2005 & 426 & 0.2746 & 0.4469 & 0.0000 & 1.0000
\end{tabular}

Tables 6 and 7 present the correlation matrix for Tobins' $\mathrm{Q}$ and entrenchment proxies, and for ROA and entrenchment proxies respectively. As can be seen in Table 6, the highest correlation is 0.4465 between Tobins' Q and firm size, and all variables yield correlation coefficient lower than $20 \%$. While the rest of the variables yield lower correlation between each other. Similarly, in Table 7 all the correlation coefficients are lower than $20 \%$. Low correlation coefficients for both regression models suggest that multicollinearity is not a problem.

Table 6

Correlation Matrix for Tobins' $Q$ and Entrenchment Proxies

\begin{tabular}{|c|c|c|c|c|c|c|}
\hline Variable & Tobins' Q & Entrenchment 1 & Entrenchment 2 & Entrenchment 3 & Firm size & Leverage \\
\hline Tobins' Q & 1.0000 & & & & & \\
\hline Entrenchment 1 & 0.0282 & 1.0000 & & & & \\
\hline Entrenchment 2 & 0.1082 & 0.0076 & 1.0000 & & & \\
\hline Entrenchment 3 & -0.0761 & -0.0398 & -0.0215 & 1.0000 & & \\
\hline Firm size & 0.4465 & 0.1735 & 0.0428 & -0.0892 & 1.0000 & \\
\hline Leverage & -0.1794 & 0.0383 & -0.0960 & 0.1965 & -0.0637 & 1.0000 \\
\hline
\end{tabular}

Table 7

Correlation Matrix for ROA and Entrenchment Proxies

\begin{tabular}{lcccccc}
\hline Variable & ROA & Entrenchment 1 & Entrenchment 2 & Entrenchment 3 & Firm size & Leverage \\
\hline ROA & 1.0000 & & & & & \\
Entrenchment 1 & 0.1616 & 1.0000 & & & & \\
Entrenchment 2 & 0.0306 & 0.0076 & 1.0000 & & & \\
Entrenchment 3 & 0.0506 & -0.0398 & -0.0215 & 1.0000 & & \\
Firm size & 0.1715 & 0.1735 & 0.0428 & -0.0892 & 1.0000 & 1.0000 \\
Leverage & -0.1031 & 0.0383 & -0.0960 & 0.1965 & -0.0637 & \\
\hline
\end{tabular}

Table 8 presents the regression result for Tobins' Q using the GLS regression model. There are three regression results; the researchers regress the independent variable one by one to observe the significance changes of variable included in each regression model. Surprisingly, there seems no significant difference among three regression models. The coefficient for entrenchment 1 is -0.0661 and significant, suggesting that the entrenchment 1 has a negative impact on firm performance. The coefficient for entrenchment 2 is -0.3557 
and significant, suggesting that entrenchment 2 has a negative impact on firm performance. The coefficient for entrenchment 3 is -0.1830 and significant, suggesting that entrenchment 3 has a negative impact on firm performance. The negative and significant results for three entrenchment proxies indicate that the higher the managerial entrenchment within the company, the lower the firm performance. Furthermore, the highest coefficient among three entrenchment proxies is entrenchment 2 which is a combination of board size and female directors on board. This suggests that the larger the board size and female directors of Chinese firms the higher the managerial entrenchment. The second largest entrenchment coefficient is entrenchment 3 which is a combination of CEO duality and CEO gender. This suggests that the existence of CEO duality contributes to higher managerial entrenchment in Chinese firms. Overall, the corporate governance variables combined as an indicator of managerial entrenchment contributes to the detrimental of firm performance. In addition, the results are in contradiction to the stewardship theory for new firms whereas the managerial entrenchment for new firms is positive.

Table 8

Regression Results for Tobins' $Q$

\begin{tabular}{|c|c|c|c|}
\hline Variable & REG 1 & REG 2 & REG 3 \\
\hline \multirow[t]{2}{*}{ Constant } & $0.9481^{* * *}$ & $0.9220^{* * *}$ & $0.9310^{* * *}$ \\
\hline & $(0.0056)$ & $(0.2142)$ & $(0.2831)$ \\
\hline \multirow[t]{2}{*}{ Entrenchment 1} & $-0.1929^{* * *}$ & $-0.1488^{* * *}$ & $-0.0661^{* * *}$ \\
\hline & $(0.0100)$ & $(0.0108)$ & $(0.0111)$ \\
\hline \multirow[t]{2}{*}{ Entrenchment 2} & & 0.0093 & $-0.3577^{*}$ \\
\hline & & $(0.1805)$ & $(0.1842)$ \\
\hline \multirow[t]{2}{*}{ Entrenchment 3} & & & $-0.1830^{* * *}$ \\
\hline & & & $(0.0494)$ \\
\hline \multirow[t]{2}{*}{ Firm size } & $0.7084^{* * *}$ & $0.6887^{* * *}$ & $0.8933^{* * *}$ \\
\hline & $(0.0045)$ & $(0.0053)$ & $(0.0430)$ \\
\hline \multirow[t]{2}{*}{ Leverage } & $-0.3729^{* * *}$ & $-0.5160^{* * *}$ & -0.0940 \\
\hline & $(0.0361)$ & $(0.0368)$ & $(0.0749)$ \\
\hline \multirow[t]{2}{*}{ IPOs_2000 } & $0.5153^{* * *}$ & $0.5370^{* * *}$ & $0.3621^{* * *}$ \\
\hline & $(0.0362)$ & $(0.0425)$ & $(0.1265)$ \\
\hline \multirow[t]{2}{*}{ IPOs_2001 } & $0.4601^{* * *}$ & $0.3247^{* * *}$ & 0.0764 \\
\hline & $(0.0320)$ & $(0.0380)$ & $(0.1282)$ \\
\hline \multirow[t]{2}{*}{ IPOs_2002 } & -0.0807 & -0.0680 & -0.2111 \\
\hline & $(0.1597)$ & $(0.1670)$ & $(0.1503)$ \\
\hline \multirow[t]{2}{*}{ IPOs_2003 } & -0.1259 & -0.2200 & -0.1401 \\
\hline & $(0.2270)$ & $(0.2002)$ & $(0.1754)$ \\
\hline IPOs_2004 & (omitted) & (omitted) & (omitted) \\
\hline IPOs_2005 & (omitted) & (omitted) & (omitted) \\
\hline Groups & 142 & 142 & 142 \\
\hline Wald-chi2 & $1291.00^{* * *}$ & 5889.6 & $1078.10^{* * *}$ \\
\hline Prob.chi2 & 0.0000 & 0.000 & 0.0000 \\
\hline
\end{tabular}

Note. Standard errors in parentheses are for coefficients. ${ }^{*}$ Sig. at $10 \%$ level; ${ }^{* *}$ sig. at $5 \%$ level; and ${ }^{* * *}$ sig. at $1 \%$ level.

However, the contradictory results may be due to that Chinese firms are different from the US firms and 
other developed countries in which the majority studies of managerial entrenchment were conducted. There are some reasonable explanations which may support the negative result for managerial entrenchment in Chinese firms. First, the majority of firms' shares in China are owned by their government by direct or indirect shareholdings through state-owned institutions such as state investment companies, state holding companies, and state assets management agencies. The major non-state ownership is individual shareholding (non-state investors are rarely). Therefore, the government direct or indirectly interfered with the governance conduct for each company they invested in; hence the managerial entrenchment is higher, and leads to lower firm performance. These practices caused a defect of corporate governance structure in the corporatised SOEs inheriting from the public ownership.

Chen, Fan, and Wong (2004) reported that almost $50 \%$ of the directors are appointed by state controlling owners, and they occupy most board seats in China. In addition, Fan et al. (2007) reported that almost $28 \%$ of the CEOs are current or ex-government bureaucrats. Chen, Fan, and Wong (2007) argued that the appointment of politically-connected CEOs does not enhance shareholders value but rather pursue political goals of politician. In addition, the lower mean of outside directors found in this study, which is 0.2149 , support the facts that the Chinese listed firms on the board of directors' front is considerable less. Further, the controlled-based model is adopted as the corporate governance practices by the Chinese listed firms. The controlling shareholders (the state) tightly control the listed firms through concentrated ownership, management friend boards and low transparency in their operations. In the end, the inefficient corporate governance structure provided the managers the opportunities to personalise their own interests or even conducted asset-stripping behaviour.

Furthermore, the coefficient for firm size is 0.8933 and significant, suggesting that larger firms tend to have higher firm performance. This result supports the fact that the market capitalisation in China is considerably high, thus attracted investors to acquire capital gain. Further, the coefficient for leverage is -0.0910 and insignificant.

Table 9 presents the regression results for ROA using the OLS between estimators' regression model. There are three regression results; the researchers regress the independent variable one by one to observe the significance changes of variable included in each regression model. Surprisingly, there seems no significant difference among three regression models. The coefficient for entrenchment 1 is 0.0100 and significant, suggesting that the entrenchment 1 has a positive impact on firm performance. Apart from entrenchment 1, the coefficient for entrenchment 2 and entrenchment 3 are insignificant. The positive and significant results for only entrenchment 1 proxy indicate that the higher the managerial entrenchment within the company, the higher the firm performance. The results are in line with the stewardship theory for new firms whereas the managerial entrenchment for new firms is positive.

The three entrenchment proxies' results for Tobins' $\mathrm{Q}$ and ROA are different, whereas Tobins' Q resulted negative impact on firm performance and ROA resulted positive impact on firm performance. This seems to be inconclusive result, but this study confidently assures that Tobins' $Q$ has more power in explaining the firm performance of new public firms, as Tobins' $Q$ reflected a market measure rather than accounting measure. In addition, due to the speculative nature of the Chinese capital markets and low quality in the accounting information, ROA alone probably does not reflect fundamentals in China's stock market (Wang \& Xu, 2004). 
Table 9

Regression Results for ROA

\begin{tabular}{llll}
\hline Variable & REG 1 & REG 2 & REG 3 \\
\hline Constant & $-0.0720^{* * *}$ & $-0.0622^{*}$ & $-0.0863^{* * *}$ \\
& $(0.0120)$ & $(0.0365)$ & $(0.0356)$ \\
Entrenchment 1 & $0.0097^{* * *}$ & $0.0098^{* * *}$ & $0.0100^{* * *}$ \\
& $(0.0034)$ & $(0.0039)$ & $(0.0029)$ \\
Entrenchment 2 & & -0.0099 & -0.0085 \\
& & $(000296)$ & $(0.0320)$ \\
Entrenchment 3 & & 0.0187 \\
& & & $(0.0127)$ \\
Firm size & $0.0406^{* * *}$ & $0.0410^{* * *}$ & $0.0440^{* * *}$ \\
& $(0.0043)$ & $(0.0043)$ & $(0.0034)$ \\
Leverage & $-0.0302^{*}$ & -0.0308 & -0.0390 \\
& $(0.0169)$ & $(0.0197)$ & $(0.0244)$ \\
\hline IPOs_2000 & $0.0284^{* * *}$ & $0.0284^{* * *}$ & $0.0310^{* * *}$ \\
& $(0.0088)$ & $(0.0097)$ & $(0.0090)$ \\
IPOs_2001 & $0.0300^{* * *}$ & $0.0303^{* * *}$ & $0.0332^{* * *}$ \\
& $(0.0070)$ & $(0.0046)$ & $(0.0087)$ \\
IPOs_2002 & $0.0423^{* * *}$ & $0.0413^{* * *}$ & $0.0455^{* * *}$ \\
& $(0.0088)$ & $(0.0900)$ & $(0.0128)$ \\
IPOs_2003 & $($ omitted) & $($ omitted) & $($ omitted) \\
IPOs_2004 & $($ omitted) & $($ omitted) & $($ omitted) \\
IPOs_2005 & $($ omitted) & $($ omitted) & $($ omitted) \\
\hline Groups & 142 & 142 & 142 \\
Wald-chi2 & $3.00^{* * *}$ & $3.05^{* * *}$ & $3.18^{* * *}$ \\
Prob.chi2 & 0.0005 & 0.0009 & 0.0025 \\
\hline Note.Stan & & $10 \%$ lovi &
\end{tabular}

Note. Standard errors in parentheses are for coefficients. ${ }^{*}$ Sig. at $10 \%$ level; ${ }^{* *}$ sig. at $5 \%$ level; and ${ }^{* * *}$ sig. at $1 \%$ level.

\section{Conclusions}

The Chinese capital market is a typical new and transitional market. There are nonstandard problems with the size and quality of listed companies, the controlling level, the governance regulations and conducts, and the development of rules and laws. These factors lead to a low level of market transparency and trust, and thus affecting the firm's performance. This study examines the impact of managerial entrenchment, as a result of corporate governance conduct in Chinese firms, on new public firms' performance. Using 142 firms listed in the SZSE, which was collected from the GTA-RSC databases, this study uses two proxies to measure firm performance and three proxies to measure managerial entrenchment. The two proxies for firm performance are Tobins' Q and ROA, and the three proxies for managerial entrenchment are entrenchment 1, entrenchment 2, and entrenchment 3. These three entrenchment proxies are derived from the PCA. From the PCA result, each factor loading for each component are combined, and only factor loadings have value higher than \pm 0.6 are included for each components.

Further, the regression method employed for two firm performance measures is different, which it based on their specification testing results, confirming that the data are linear and no endogeneity issue should be address in this study, but only heteroskedasticty, non-normality for Tobins' Q are a problem, therefore, the regression method employed for Tobins' $\mathrm{Q}$ is the GLS and the OLS between estimators for ROA. The 
regression result for Tobins' $\mathrm{Q}$ reveals that managerial entrenchment is negatively impact on firm performance. The results are in contradictory with the stewardship theory for new firms whereas the managerial entrenchment for new firms is positive. In contrast, the regression result for ROA reveals that managerial entrenchment is positively impact on firm performance, however, only one entrenchment proxy yields a significant coefficient. The results are in line with the stewardship theory for new firms whereas the managerial entrenchment for new firms is positive.

There are some reasonable explanations which may support the negative result for managerial entrenchment in Chinese firms. First, the majority of firms' shares in China are owned by their government by direct or indirect shareholdings through state-owned institutions. Therefore, the government direct or indirectly interfered with the governance conduct for each company they invested in; hence the managerial entrenchment is higher, and leads to lower firm performance. These practices caused a defect of corporate governance structure in the corporatised SOEs inheriting from the public ownership. Further, the inefficient corporate governance structure provided the managers the opportunities to personalise their own interests or even conducted asset-stripping behaviour.

Second, in fact that financial institutions may also be able to suppress the managerial entrenchment of companies, this also unable to be applied as well to the Chinese market because the China's financial sector has been under the strong influence of the state. The state monopoly of the financial sector has been an obstacle for China's capital market to develop. Third, the China's legal and institutional framework is still immature. The different institutional structures, legal systems, and governance conducts casts doubt on whether the western models of managerial entrenchment theories have explanatory power on the entrenchment of new publicly Chinese firms in China's market.

In conclusion, the negative results of entrenchment proxies were caused by the different institutional structures and legal systems. The Chinese corporations that are still largely owned and controlled by a state resulted in the different institutional structures and legal systems, and hence the centralised state controlled was responsible for all managerial actions.

The findings of this study are restricted to the limitation of the data, which was collected through publicly available data sources such as annual reports and other databases. If there are any problems relating to data disclosures or professional accounting practices, then that would limit the validity of the findings. In addition, the entire population from period 2000 to 2005 comprises only 142 firms, which is relatively small, hence conclusions derived are only limited to the SZSE and the events happened in the year observed.

\section{References}

Baysinger, B. D., \& Butler, H. D. (1985). Corporate governance and the board of directors: Performance effects of changes in board composition. Journal of Law, Economics, and Organizations, 1, 101-124.

Bebchuk, L., Cohen, A., \& Ferrell, A. (2005). What matters in corporate governance? Harvard University, John M. Olin Center for Law, Economics, and Business, Discussion Paper No.491.

Bhagat, S., \& Black, B. (2002). The non-correlation between board independence and long-term firm performance. Journal of Corporation Law, 27(2), 231-273.

Chahine, S., \& Tohmé, N. S. (2009). Is CEO duality always negative? An exploration of CEO duality and ownership structure in the Arab IPO context. Corporate Governance: An International Review, 17(2), 123-141.

Chen, D. H., Fan, J., \& Wong, T. J. (2004). Political connected CEOs, corporate governance and post-IPO performance of China's partially privatized firms. Working Paper, Center for Economic Institutions Working Paper Series, Institute for Economic Research, Hitotsubashi University, Japan. 
DeAngelo, H., DeAngelo, L., \& Stulz, R. (2006). Dividend policy and the earned/contributed capital mix: A test of the life-cycle theory. Journal of Financial Economics, 81, 227-254.

Donaldson, L. (1990). The ethereal hand: Organizational economics and management theory. Academy of Management Review, 15, 369-381.

Fama, E. F., \& French, K. R. (2001). Disappearing dividends: Changing firm characteristics or lower propensity to pay? Journal of Financial Economics, 60, 3-43.

Fan, J. P. H., Wong, T. J., \& Zhang, T. (2007). Politically connected CEOs, corporate governance, and post-IPO performance of China's newly partially privatized firms. Journal of Financial Economics, 84, 330-357.

Gao, L., \& Kling, G. (2008). Corporate governance and tunneling: Empirical evidence from China. Pacific-Basin Finance Journal, 16(5), 591-605.

Gompers, P., Ishii, J., \& Metrick, A. (2003). Corporate governance and equity prices. Quarterly Journal of Economics, 118, 107-155.

Gu, A. Y. (2003). State ownership, firm size, and IPO performance: Evidence from Chinese "A" share issues. American Business Review, 21(2), 101.

Hermalin, B., \& Weisbach, M. (1991). The effects of board composition and direct incentives on firm performance. Financial Management, 20, 101-112.

Holderness, C., Kroszner, R., \& Sheehan, D. (1999). Were the good old days that good? Evolution of managerial ownership and corporate governance since the great depression. Journal of Finance, 54, 435-469.

Jensen, M. C., \& Meckling, W. H. (1976). Theory of the firm: Managerial behavior, agency costs and ownership structure. Journal of Financial Economics, 3(4), 305-360.

Li, L., \& Naughton, T. (2007). Going public with good governance: Evidence from China. Corporate Governance: An International Review, 15(6), 1190-1202.

Lin, Z. J., \& Liu, M. (2009). The impact of corporate governance on auditor choice: Evidence from China. Journal of International Accounting, Auditing and Taxation, 18(1), 44-59.

Maddala, G. S., \& Lahiri, K. (2009). Introduction to econometrics (4th ed.). West Sussex, England: John Wiley \& Son Ltd..

McConnell, J. J., \& Servaes, H. (1990). Additional evidence on equity ownership and corporate value. Journal of Financial Economics, 27, 595-612.

Morck, R., Schleifer, A., \& Vishny, R. W. (1988). Management ownership and market valuation: An empirical analysis. Journal of Financial Economics, 20, 293-316.

Muth, M., \& Donaldson, L. (1998). Stewardship theory and board structure: A contingency approach. Corporate Governance: An International Review, 6(1), 5-28.

Rosenstein, S., \& Wyatt, J. (1990). Outside directors, board independence and shareholder wealth. Journal of Financial Economics, 26, 175-191.

Shleifer, A., \& Vishny, R. W. (1989). Management entrenchment: The case of manager specific investments. Journal of Financial Economics, 25, 123-140.

Shleifer, A., \& Vishny, R. W. (1997). A survey of corporate governance. Journal of Finance, 52(2), 737-783.

Short, H., \& Keasey, K. (1999). Managerial ownership and the performance of firms: Evidence from the UK. Journal of Corporate Finance, 5, 79-101.

Wang, F., \& Xu, Y. (2004). What determines Chinese stock returns? Financial Analysts Journal, 6(6), 65-67.

Weisbach, M. S. (1988). Outside directors and CEO turnover. Journal of Financial Economics, 20, 431-460.

Wintoki, M. B., Linck, J. S., \& Netter, J. M. (2009). Endogeneity and the dynamic of corporate governance. European Summer Symposium in Financial Markets (pp. 13-24, 1-52). Centre for Economic Policy Research.

Yermack, D. (1996). Higher market valuation of companies with a small board of directors. Journal of Financial Economics, 40, $185-211$. 